\title{
Morphology of fluvial levee series along a river under human influence, Maros River, Hungary
}

\author{
Tímea Kiss a,*, Márton Balogh a , Károly Fiala ${ }^{\mathrm{b}, *}$, György Sipos ${ }^{\mathrm{a}}$ \\ a Department of Physical Geography and Geoinformatics, University of Szeged, Szeged 6722, Egyetem u. 2-6, Hungary \\ b Lower Tisza District Water Directorate, Szeged 6720, Stefánia 4, Hungary
}

\section{A R T I C L E I N F O}

\section{Article history:}

Received 17 July 2017

Received in revised form 8 December 2017

Accepted 9 December 2017

Available online 12 December 2017

\section{Keywords:}

Fluvial levee

Human activity

Channel-floodplain connection

LiDAR

\begin{abstract}
A B S T R A C T
The development and morphometry of fluvial levees reflect the connection between channel and overbank processes, which can be altered by various human activities. The aims of this study are to investigate the morphology and spatial characteristics of fluvial levees and evaluate the role of some local- and catchment-scale human activities on their medium-term (150 years) development. This study applies LiDAR data along a 53-km-long reach of the Maros River in Hungary.

Six fluvial levee types are identified based on the beginning and end of their evolution. These levee types were generated by local nineteenth century channel regulation works (cutoffs) and mid-twentieth century channel narrowing, which was caused by gravel mining and water impoundment in the upstream sections. However, other human activities also influenced the development of active fluvial levees because their horizontal evolution could have been limited by embanked flood-protection levees or the widening of low-lying floodplain benches that were generated by channel narrowing. Additionally, revetment constructions influenced their vertical parameters as higher fluvial levees developed along the fixed banks. Generally, the older active fluvial levees are wider, while the younger active levees are narrower with steeper slopes but not always lower. On the lowlying floodplain levels (benches), the youngest fluvial levees evolved quite rapidly and consist of coarser material. Currently, only 9.8- to 38-year return-period floods could cover the fluvial levees, contributing to their evolution. This fact and the development of fluvial levee series with two-three members reflect a gradual decoupling of the channel from the floodplain.
\end{abstract}

(c) 2017 Elsevier B.V. All rights reserved.

\section{Introduction}

Fluvial (natural) levees are common features along low-gradient channels (Nanson and Croke, 1992) that control the relationship between instream and overbank processes (Brierley et al., 1997). Fluvial levees are ribbon-like accumulation forms that rise above the floodplain (Nanson and Croke, 1992; Smith, 1996) along concave banks (Fisk, 1947; Allen, 1965; Zwolinski, 1992) and next to straight reaches of different channel patterns (Brierley et al., 1997). Their development is connected to floods, when the velocity decreases because of a rapid drop in the water column and because of the increased roughness from vegetation (Hughes, 1997; Piégay et al., 2003; Dufour and Piégay, 2005; Steiger et al., 2005). Thus, coarse grains accumulate along the banks to form fluvial levees, while finer grains can aggrade on the distal portion of the floodplain (Wolman and Leopold, 1957; Middelkoop and Asselmann, 1998; Wolfert et al., 2002; Kiss et al., 2004; Sándor, 2011). Fluvial levees appear along laterally stable sections

\footnotetext{
* Corresponding author.

E-mail addresses: kisstimi@gmail.com (T. Kiss), metusmail@gmail.com (M. Balogh), fialak@ativizig.hu (K. Fiala),gysipos@geo.u-szeged.hu (G. Sipos).
}

(Nanson and Croke, 1992); therefore, if the fluvial system loses its equilibrium, these levees can also be altered (Adams et al., 2004; Abate et al., 2015). However, only a limited amount of research has been conducted on the modification of fluvial levees because of human disturbances (Klasz et al., 2014).

A morphometric analysis of fluvial levees revealed that narrower (and younger) forms tended to be steeper and that the farther the sediments were transported from the bankline, the gentler the slope of the fluvial levee became (Cazanacli and Smith, 1998). However, contradictory results were observed when the morphology of fluvial levees was correlated to the hydromorphological parameters of the adjacent channel and floodplain. According to Hudson and Heitmuller (2003), the levees' size corresponded to the sediment transport characteristics and medium-term (100-1000 years) changes in the flow regime. Higher floods usually have higher flow velocity and sediment discharge and thus can create larger levees (Brown, 1983; Chalov, 2004; Keen-Zebert et al., 2013). The size of fluvial levees is also influenced by the slope of the river (Fryirs and Brierley, 2012), its discharge (Taylor, 2002; Sorrells, 2012), the width and configuration of the floodplain (Pierik et al., 2017), and the density of riparian vegetation (Steiger et al., 2005). However, in contrast to earlier studies, Adams et al. (2004) 
concluded that the dimensions of levees were independent of the channel size, bankfull channel area, or grain size, although their morphology was controlled by the position of the fluvial levee on the meander, channel age, flood frequency, and vegetation type and density. According to Hudson and Heitmuller (2003), the width of fluvial levees was inversely correlated to the radius of the curvature of meanders. Klasz et al. (2014) hypothesised that the height of fluvial levees corresponded to the width of the adjacent floodplain: high fluvial levees developed in wide floodplains, while low levees formed in narrow floodplains because of water backflow into the main channel. Contradictory ideas exist regarding the factors that influence the spatial development of levees because few studies have been conducted on the morphology of fluvial levees and because they represent quite different environments. Catchment-scale and local human activities can alter all the above parameters (e.g., flood characteristics, channel geometry, transported sediment, floodplain width), so our hypothesis is that the evolution and dimensions of fluvial levees could be altered by anthropogenic activities, especially on rivers that have been intensively regulated, such as the Maros River in Hungary.

Fluvial levees show large variations in dimension and diverse grainsize distributions, indicating an intermediate nature between the channel and the floodplain (Cazanacli and Smith, 1998), as their material is coarser than the sediments of the floodplain but finer than the bedload (Brierley et al., 1997). At the beginning of development, coarse sediment is transported from the channel and deposited within a short distance, initially forming narrow, steep, and coarse-grained fluvial levees. Fluvial levees become higher and finer grained because of ongoing overbank aggradation, and eventually only large floods can overflow them (Cazanacli and Smith, 1998). The farther the sediments are transported from the bankline, the lower the slope of a fluvial levee becomes (Cazanacli and Smith, 1998).

Considering the rate of fluvial levee aggradation, Smith and PérezArlucea (2008) found that thicker fluvial levee material was deposited at sections where the channel widened after a large flood, whereas thinner deposits occurred along aggrading or slightly enlarging channel sections. Xu (2002) found a negative correlation between the vertical deposition rates of the riverbed and the fluvial levee. Over decades and centuries, the height increase $(0.6-2.3 \mathrm{~mm} / \mathrm{y})$ of fluvial levees has been quite slow in various climatic zones with local human activity (Stevaux and Souza, 2004; Makaske et al., 2009; Trimble, 2009); however, as much as $0-70 \mathrm{~cm}$ of levee material could be deposited during large floods (Smith and Pérez-Arlucea, 2008; Sándor, 2011). Under natural conditions, this aggradation is balanced by erosion and lateral channel migration. However, if the channel is stabilised, the height increase of fluvial levees can be as much as $11.0 \mathrm{~mm} / \mathrm{y}$ on average (Klasz et al., 2014). The mismanagement of a floodplain can increase the density of vegetation, resulting in accelerated fluvial levee development in a narrowing strip along the channel (Sándor, 2011). The rate of fluvial levee development can also be accelerated in connection with increased sediment load from a mining area (James et al., 2012).

The horizontal dimensions of fluvial levees vary from metres to several kilometres, while their vertical parameters vary from centimetres to metres (Allen, 1965) depending on the hydromorphological characteristics of the river. Fluvial levees are vertically small landforms, so precise surveys by classical topographical mapping are difficult; in addition, field surveys of large and densely vegetated floodplain areas can be very laborious. In most previous studies, few fluvial levee profiles were analysed (Cazanacli and Smith, 1998; Adams et al., 2004) or studied on maps and aerial photographs (Hudson and Heitmuller, 2003); alternatively, the depth of levee material was measured along a reach after a single flood (Smith and Pérez-Arlucea, 2008; Sándor, 2011). High-resolution LiDAR data have become widely available so that scientists could obtain fast and accurate terrain measurements across large areas (Notebaert et al., 2009; Wierzbicki et al., 2013; Klasz et al., 2014; Palaseanu-Lovejoy et al., 2014).

All these studies refer to single ridges but not to series of fluvial levees, although they appear in succession along the Maros River in
South Hungary. Furthermore, these fluvial levee series have developed along a section that is under various human influences. Among the local engineering works, artificial cutoffs, revetments, and embanked levees have been constructed; while inchannel gravel mining and water retention have been conducted in more upstream sections. These engineering measures offer a unique possibility to study the role of anthropogenic disturbances on fluvial-levee development. Additionally, a new LiDAR data set (2014) provides a great opportunity to identify and morphologically evaluate fluvial levees along a 53.7-km-long reach of the Maros River.

The aims of this study are to investigate the spatial characteristics of the fluvial levee series and evaluate the role of reach-scale (e.g., cutoff, revetment, and embanked levee constructions) and catchment-scale (e.g., water retention and inchannel gravel mining) human activities on their development. These upstream human influences combine and influence the development of fluvial levees through channel narrowing and floodplain-bench formation. Our specific goals are to (i) identify fluvial levees on the embanked floodplain, (ii) measure their horizontal and vertical parameters, reveal changes in their (iii) temporal and spatial characteristics and (iv) grain-size distribution, and ( $v$ ) evaluate the role of human activities in their evolution. This study contributes to our understanding of medium-term (150 years) fluvial-levee development along a highly altered river channel and increases our knowledge regarding the changing linkage (coupling) between channels and their floodplains.

\section{Study area}

The Hungarian Maros floodplain was studied in detail along a 53.7-km-long section from Nagylak (Nadlac) to Szeged (Fig. 1). The Maros constitutes the border between Romania and Hungary along the upstream section (53.7-28.0 km; units 1-8) and then flows entirely within Hungary until its confluence with the Tisza River $(28-0 \mathrm{~km}$, units 9-31). Thus, the Hungarian LiDAR survey covered only the northern portion of the floodplain along the upstream section, while floodplains on both banks were analysed in the downstream section.

The study area stretches across the Quaternary alluvial fan and the adjacent floodplain of the Maros River (Kiss et al., 2011, 2014), and these macroforms influence the slope conditions of the river and thus the depositional environment in the embanked floodplain (Kiss et al., 2011; Sümeghy, 2014). The uppermost section (units 1-8) of the study area is located on the alluvial fan, where the channel slope is the steepest (0.00038), and then the channel slope on the front of the fan (units 9-11) decreases (0.00022). The next geomorphological macroform is the secondary alluvial fan (12-20 units, channel slope: 0.00012 ), which developed between the embanked flood-protection levees (Kiss et al., 2011). After leaving the area of the alluvial fan, the river flows across its natural floodplain (units 21-24, slope: 0.00005) and finally reaches the outlet (units 25-31, slope: 0.00002) near the confluence with the Tisza River. Thus, the channel slope decreases by a factor of 18 along the 53.7-km-long studied section of the Maros.

Hydrological data from the Makó gauge station have been collected since the late nineteenth century, so the zero point of the fluviometer was set at the lowest monitored stage at that time; negative values have also been recorded because the channel was incised (Fig. 2A). Since the beginning of these measurements, the water stages $(-114-618 \mathrm{~cm})$ and the discharge values $\left(21-2450 \mathrm{~m}^{3} / \mathrm{s}\right)$ varied within a large range (Sipos et al., 2007). The discharge values of the yearly lowest stages reflect the inchannel processes. The discharge of the yearly lowest stages fitted to a line in the 1900s to 1930s (Fig. 2B). The data shifted downward in the 1940s to 1970s, indicating inchannel aggradation. In the 1980s to 2000s, the data shifted upward (e.g., greater discharge values belong to the same stage), indicating incision and an increase in the cross-sectional channel area. Since the early 1980s, the annual maximum, mean, and lowest stages decreased by $11-35 \%$. These hydrological changes in the late twentieth century were probably linked to increased water impoundment on the catchment and active inchannel gravel 


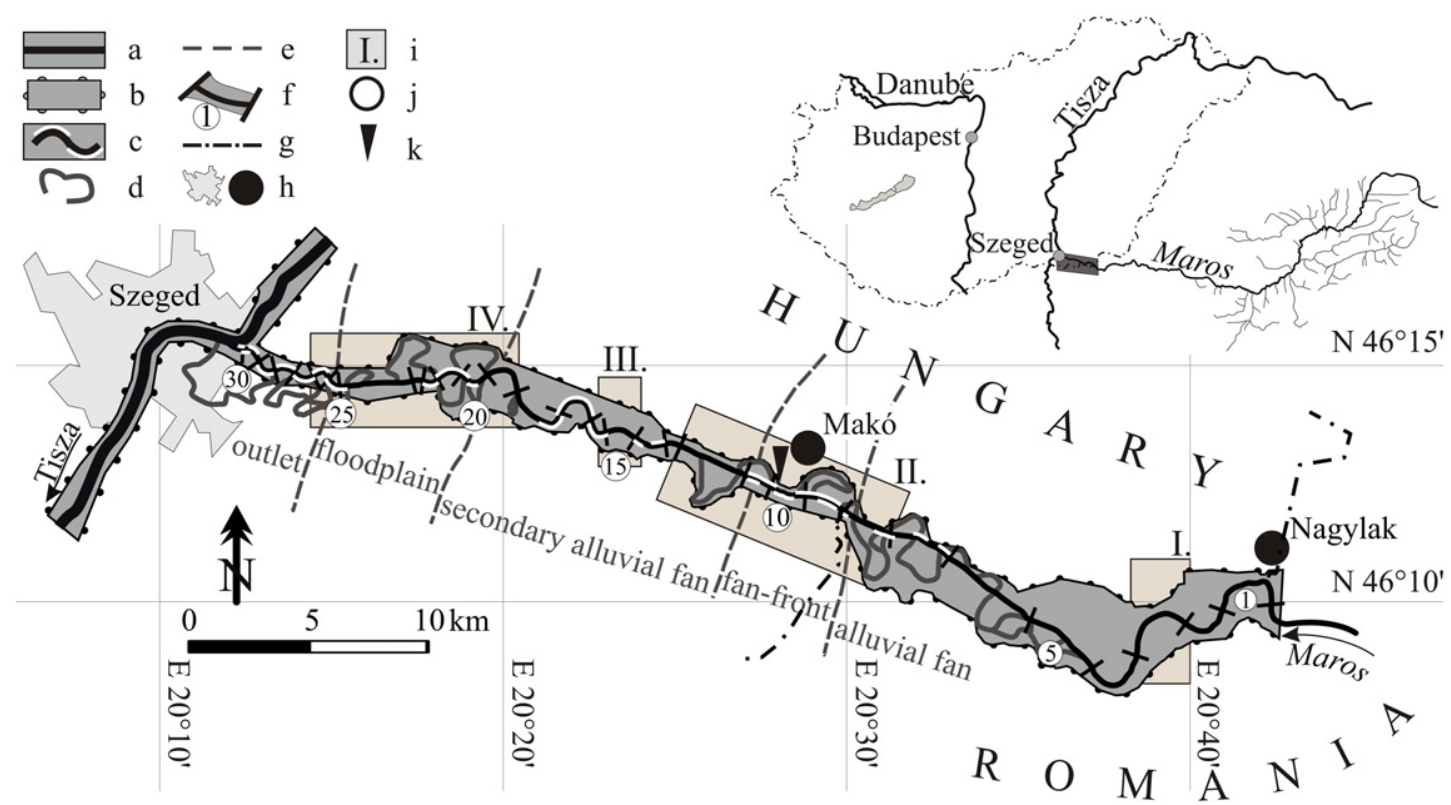

IV.

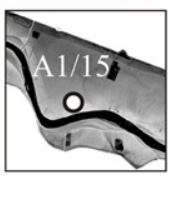

III.

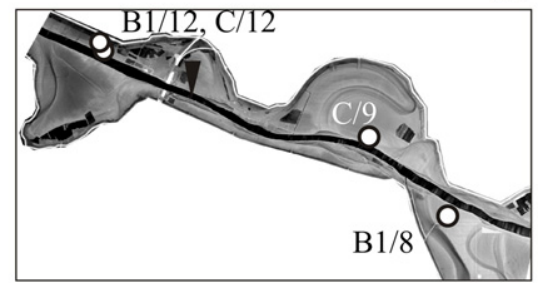

I.

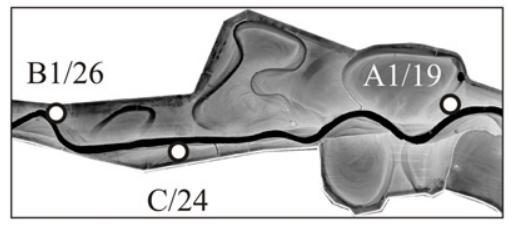

II.

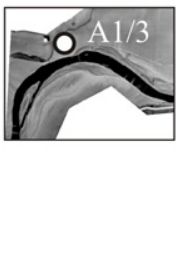

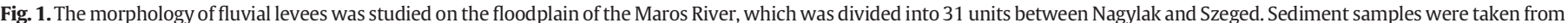

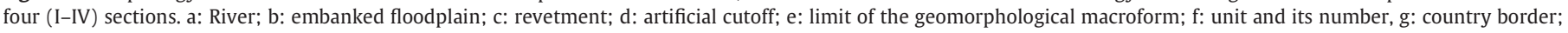
h: settlement; i: sampling site (I-IV), j: drilling point; k: gauge station.

mining in Romania ca. 70-120 km upstream of the studied section (Urdea et al., 2012; Kiss et al., 2017).

Understanding the flood history is crucial when developing fluvial levees. The bankfull level $\left(350 \mathrm{~cm}, \mathrm{ca} .730 \mathrm{~m}^{3} / \mathrm{s}\right)$ is applicable only to the gauge site because of the considerable slope changes along the Maros. In the nineteenth to twentieth centuries, floods lasted for 6-21 d/y; however, in recent decades, overbank flows lasted for only $1-1.5 \mathrm{~d} / \mathrm{y}$ or did not occur at all (Kiss, 2014). The recurrence interval of the bankfull stage based on the long-term (116 years) record is 2.3 years (Fig. 3 ). Floods in the Maros and Tisza rivers usually coincided, so the floods in the Maros were naturally impounded by the Tisza, which influenced the flow conditions and sediment deposition along its lower, ca. 28-km-long section (Kiss et al., 2011); however, no data exist regarding the influence of this impoundment on the flow velocity or sediment transport.

The Maros has considerable sediment discharge. The only measurements were conducted by Bogárdi (1971), according to which the mean suspended load is $265 \mathrm{~kg} / \mathrm{s}$ ( 8.3 million t/y) and the bedload is $0.9 \mathrm{~kg} / \mathrm{s}$ $(28,000 \mathrm{t} / \mathrm{y})$. The bedload is dominated by fine gravel $(2-4 \mathrm{~mm})$ in the upstream section (1-11 units) but by sand in the downstream section (0.4-0.7 mm; Laczay, 1975). Therefore, very intensive $(1.2-2.5 \mathrm{~cm} / \mathrm{y})$ vertical accumulation characterised the floodplain from the midnineteenth until the mid-twentieth centuries, around the time of the cutoffs and embanked levee constructions (Oroszi et al., 2005; Kiss et al., 2011). This phenomenon can be explained by the intensive widening and deepening of the artificial channel sections, which increased

\section{(A)}

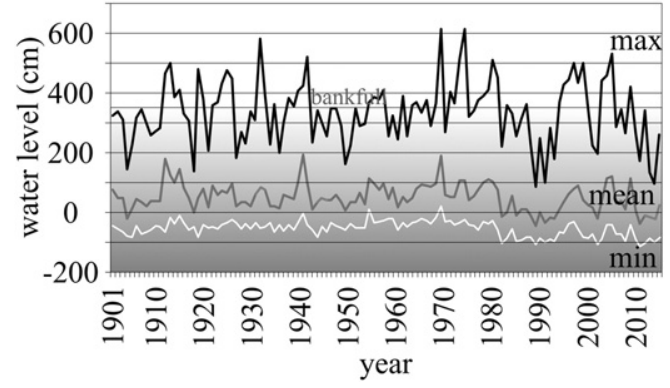

(B)

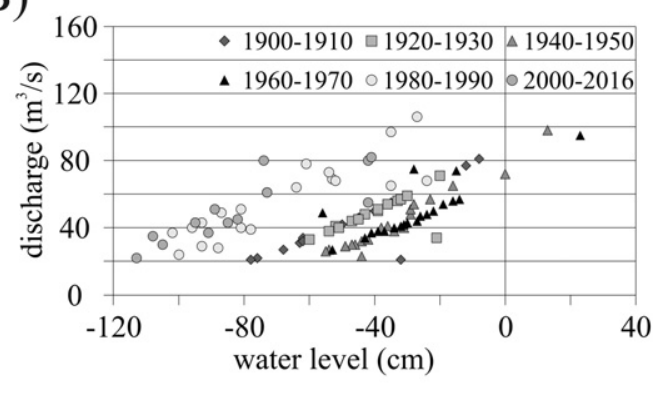

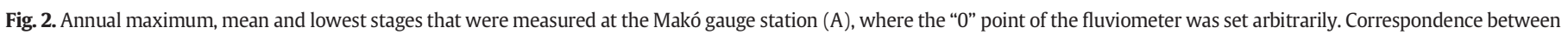
the yearly lowest stage and its discharge (B). 


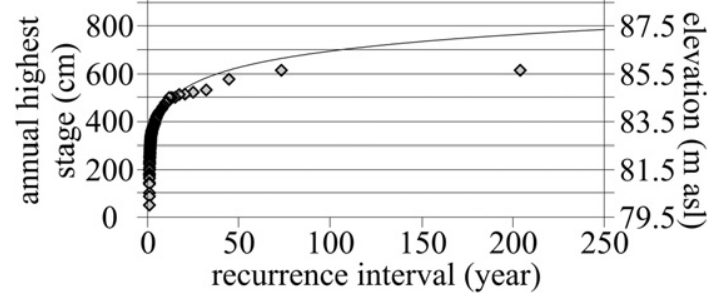

Fig. 3. Recurrence interval ( $y$ ) of the yearly highest stages of the Maros River at the Makó gauge station and the elevation ( $\mathrm{m}$ asl) of the stages.

the sediment transport and accelerated aggradation on the narrower embanked floodplain. In the second half of the twentieth century, overbank aggradation became limited because of shorter floods, channel narrowing, and incision (Oroszi and Kiss, 2004; Blanka and Kiss, 2006).

On the Maros River, embanked levee constructions began in the 1850s (Ihrig, 1973). These features were built simultaneously with channel regulations and along the nineteenth-century meanders, so the width of the embanked floodplain varies $(0.4-3.8 \mathrm{~km})$. The upstream floodplain of the study area (units 1-9) is wider (1.0-3.8 km), while the lower area (units 10-31) is much narrower $(0.4-1.8 \mathrm{~km}$; Fig. 1). Within the frame of channel regulations (1840-1871), 24 meanders and channel fragments were cut off in the study area (Fig. 1; Laczay, 1975). These cutoffs affected the channel in units 5-31. A 9-km-long channel fragment was cut off close to the conjunction, so a new, sinuous artificial channel was created here (units 25-31). During regulation works, the increased slope accelerated bank erosion and channel incision (ca. $1.0 \mathrm{~m}$ ), which combined with the increased sediment transport to create islands and inchannel bars, so an islandbraided channel pattern developed along the upstream section (units 1-11). Meanwhile, the lower section downstream of Makó (units 12-31) remained sinuous. Since World War I, the upper section of the study area has constituted the border between Romania and Hungary, so engineering works were not allowed here. However, stone revetments were built (1946-1958) along an 18.3-km stretch to stabilise the banks within the 28-km-long lower section (units 12-31) (Sipos, 2006). The number of groynes is negligible.

In addition to these local-scale engineering works, catchment-scale and upstream human activity has influenced the development of the study area. In Romania, inchannel gravel mining between Lipova and Arad (ca. 70-120 km upstream of the study area) was intensive between the 1960s and 2000s, which resulted in 2.6-6.8 m of incision within the mined section. The incision propagated downstream along the upstream portion of the studied section (units 1-11), measuring $1.2 \mathrm{~m}$ on average (Kiss et al., 2017). Meanwhile, the Tisza River was also regulated, and its channel was incised by 2-2.5 m (Ihrig, 1973; Szlávik, 2000), which propagated upstream along the Maros. This headward incision combined with the incision that was propagating from upstream, so the incision along the lower section (units 12-31) was $1.9 \mathrm{~m}$ on average (Kiss et al., 2017).

\section{Methods}

\subsection{Measuring the morphometric parameters}

A digital terrain model (DTM) that was based on a LiDAR survey (provided by the Lower Tisza District Water Directorate) was applied to identify and measure the morphometric parameters of fluvial levees. This LiDAR survey was conducted in the winter of 2014 to minimise the effects of vegetation on the resulting elevation data. The vertical accuracy of the DTM is $\pm 0.1 \mathrm{~m}$ based on the resurveying of 525 points along the entire floodplain. The DTM covers an area of $96 \mathrm{~km}^{2}$ and has a resolution of $4 \mathrm{~m}^{2}$. The morphological measurements were performed with the ArcGIS 10.2 software.

On the DTM, fluvial levees appeared as almost continuous features along slightly sinuous bends but alternated with point bars along meandering sections; therefore, their lengths were not measured. However, each bend had its own fluvial levee, so the studied reach of the Maros was divided into 31 units (bends). The boundaries of the units were perpendicular lines to the banks across the inflection points of straight sections between the bends (see Laczay, 1982). To locate the narrowing sections, the banklines were delineated on the third Hungarian Military Survey (created in 1881 shortly after the channel regulations) on geocorrected aerial photos from 1953 and the LiDAR survey (2014). The channel width was measured at every $100 \mathrm{~m}$ along the centre line of the river. The width changes were calculated in percentages (\%) compared to the beginning of the periods (1881-1953 and 19532014). Floodplain surfaces (benches) were identified as low-lying areas between the 1881 and 2014 banklines.

In each unit, the morphometry of the fluvial levees was measured along cross-sectional profiles on the DTM and drawn perpendicular to the centre line of the river across the highest point of a fluvial levee. The boundaries of each fluvial levee were defined by the bankline and the breaking point of the outer slope (Fig. 4) because the terrain on the distal portion of the floodplain is almost flat (see Cazanacli and Smith, 1998; Adams et al., 2004). The width (W) of each fluvial levee was measured between these boundaries, and the height $(H)$ was measured between the highest and lowest (distal) points of the natural levee. The slope $(S)$ of the surface of each fluvial levee $(\mathrm{m} / \mathrm{m})$ was calculated from the ratio of the distance between the highest and lowest points along the outer slope $(d)$ and relative height $(H)$.

The elevation ( $\mathrm{m}$ asl) of the highest points of the fluvial levees were known, so we could calculate the recurrence interval $(R I)$ of floods, which could cover the levees and contribute to their aggradation. The RI was calculated based on the annual highest stages (1901-2016) by applying the Gringorten formula (Searcy, 1959). The role of flood RIs in fluvial-levee development was only evaluated near the Makó gauge station (units 9-15) because (i) the water stage was only measured at Makó, (ii) considerable elevation changes occurred along the studied reach, and (iii) the water levels along the downstream section were influenced by the stage of the Tisza River. Therefore, the water-level elevation that covered a given levee was corrected by the slope of the river for this calculation.
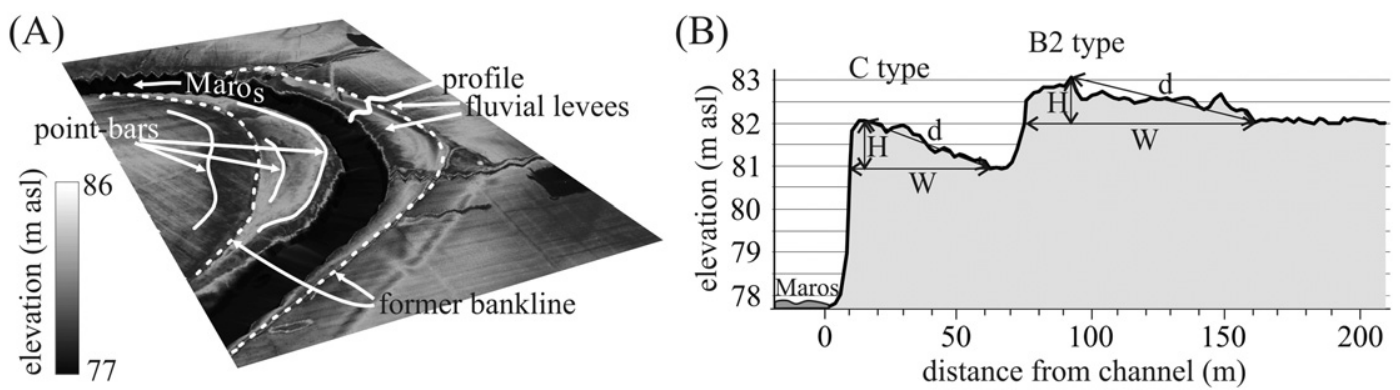

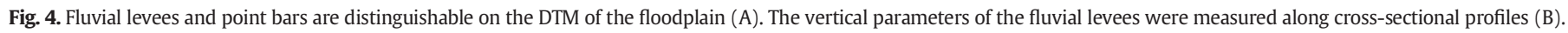




\subsection{Identifying the fluvial-levee types}

The channel development of the Maros River is modified by cutoffs, channel narrowing, and revetments; while floodplain evolution is restricted by embanked levees that are located at various distances from the channel. Bankline changes from artificial cutoffs and channel narrowing terminated the development of fluvial levees, and new fluvial levees began to develop along the new banklines. Thus, double or triple fluvial levees evolved, similarly to a series of point bars. Altogether, six fluvial levee generations are distinguishable along the studied reach of the Maros River (Fig. 5):

(A) Fluvial levees developed at the time of the nineteenth century river regulations with

(A1) continuous (active) development ever since;

(A2) terminated development because of channel narrowing since the 1950s; and

(A3) terminated development because of an artificial cutoff in the nineteenth century.

(B) Fluvial-levee development began during the nineteenth century river regulations when a cutoff was built, and fluvial levees began to develop along the new artificial channel with

(B1) continuous (active) development since that time; and.

(B2) terminated development because of channel narrowing since the 1950s.

(C) The youngest, active fluvial levees began to develop when the channel became narrower (since the 1950s), and the evolution of a new fluvial levee began on the low floodplain benches.

\subsection{Grain-size analysis of the fluvial levees}

Materials from different fluvial-levee types were sampled to evaluate the downstream variability in the grain size. Fluvial levees were selected along the straight upstream section (units 3 and 8-9), middle section (units 12 and 15) and downstream section (units 19, 14, and 26) of the Maros. These sediment samples (19) were collected on the highest points of the landforms from the uppermost sandy layer, where this material was probably deposited during their active evolution.

Additionally, each active fluvial-levee type was sampled along their entire depth to evaluate the grain-size changes during the evolution of the levees in the middle section of the river. Sediment samples (59) were collected by a Pürckhauer auger at $10-\mathrm{cm}$ intervals. The grain-size distribution of the samples was measured by the MasterSizer 3000 and Hydro LV module (Malvern Instruments) and evaluated by applying the Gradistrat software. The sediment profiles were dissected into zones and subzones based on similarities and differences in the grain size.

\section{Results}

\subsection{Channel width change and bench formation}

According to earlier studies (Sipos, 2006; Kiss et al., 2017), the channel has been narrowing since the 1950s, most intensively (12-15 m/y) in the 1950s to 1960s (Blanka et al., 2006). Low-lying floodplain benches could be formed during narrowing (Erskine and Livingstone, 1999; Haney and Davis, 2015). The developed benches create space for type $C$ fluvial levees, while the evolution of older fluvial levees terminated (types A2 and B2). This channel narrowing was studied in detail.

The studied 53.7-km-long reach of the Maros River became considerably narrower over the last 130 years (Fig. 6), with the average width decreasing by 26\% (1881: $155 \mathrm{~m}$; 2014: $115 \mathrm{~m}$ ). This width reduction has been more intensive since 1953. Between 1881 and 1953, the channel width only slightly changed, becoming narrower by only $2 \%$ on average (1881: $155 \mathrm{~m}$; 1953: $152 \mathrm{~m}$ ); however, narrowing became the dominant process after 1953 . The average channel width has decreased by $24 \%$ since 1953 (1953: $152 \mathrm{~m} ; 2014: 115 \mathrm{~m}$ ), a mean narrowing rate of $0.6 \mathrm{~m} / \mathrm{y}$. This narrowing affected $88 \%$ of the studied reach. The most narrowed sections appeared to be in the upstream section (units 1-11), where the average narrowing was 26\%. The greatest width reduction was 70\% (1953: $251 \mathrm{~m} ; 2014: 76 \mathrm{~m}$ ) in unit 1, which is the uppermost unit and is situated closest to the gravel-mining area. The most intensive narrowing characterised the meandering and braided sections (units 1-21), while the channel width of the bends on the slightly sinuous downstream section (units 22-31) remained the same or even increased at the apexes of some bends.

This intensive channel narrowing created new, 20-130 m wide floodplain surfaces (benches) that were suitable for fluvial levee development, although at lower (by $0.3-1.9 \mathrm{~m}$ ) elevation.

\subsection{Horizontal and vertical dimensions of the fluvial levee types}

The LiDAR-based DTM on the floodplain of the Maros River enabled us to identify $0.2-3.1 \mathrm{~m}$ high fluvial levees. One third (36\%) of the studied forms belonged to type A (Table 1). The type A1 fluvial levees

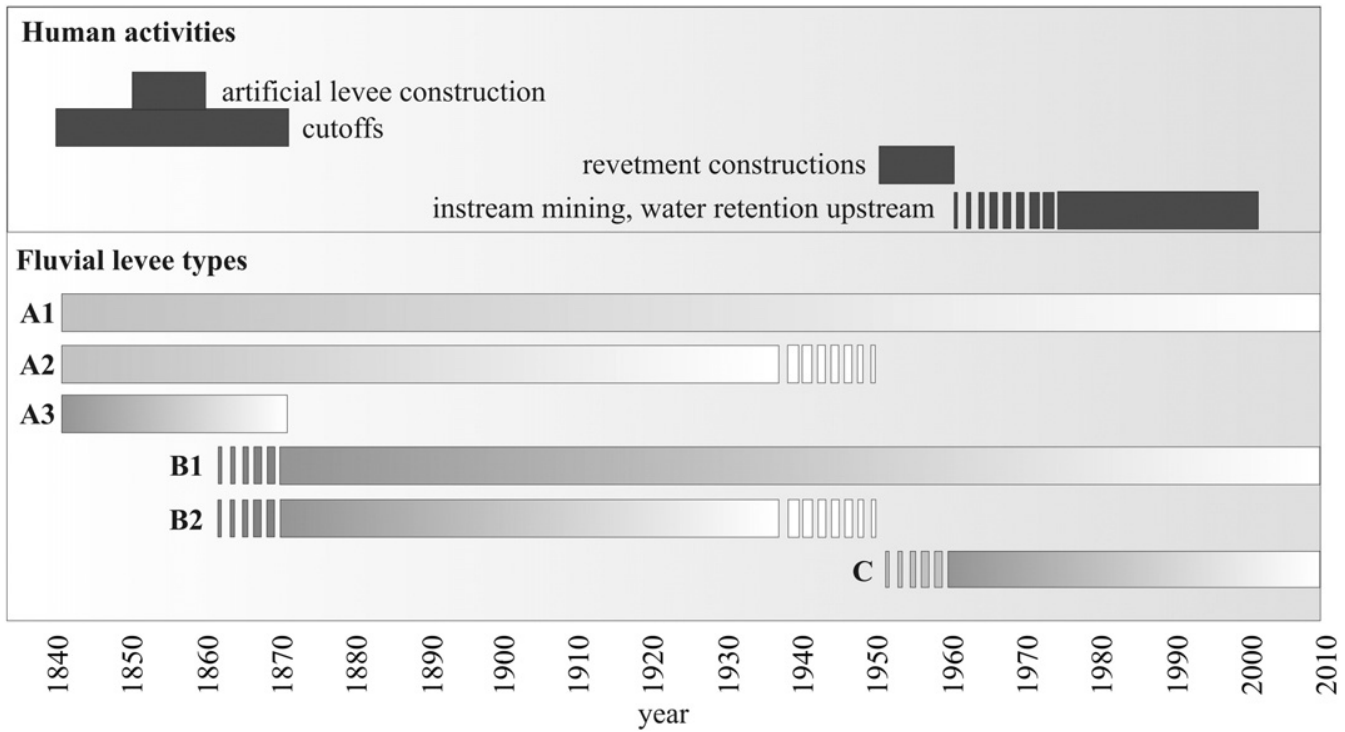

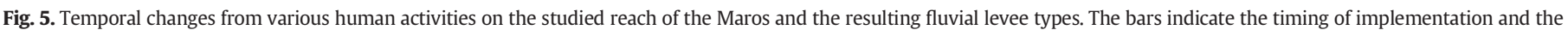
active evolution of a fluvial levee, while the broken bars refer to uncertain transformation. 


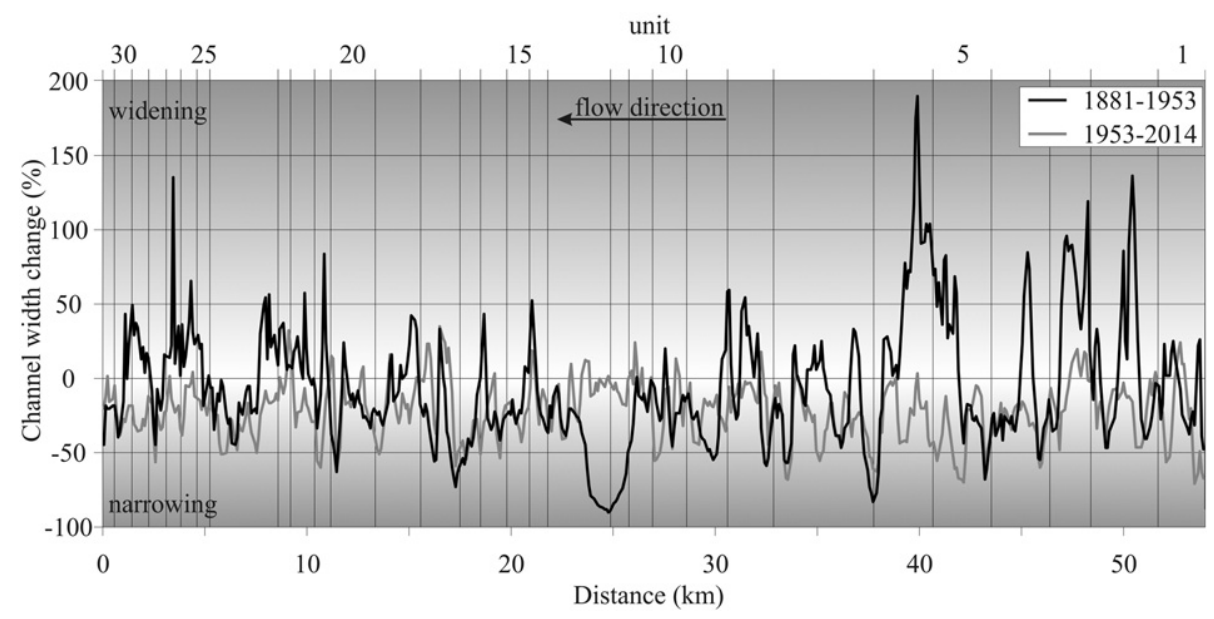

Fig. 6. Width changes (\%) in the studied reach between 1881 and 2014 and 1953-2014. New low-lying floodplain surfaces (benches) formed along narrowed sections.

developed over centuries and thus were the widest $\left(\mathrm{W}_{\text {mean }}: 441 \mathrm{~m}\right)$ and highest $\left(\mathrm{H}_{\text {mean }}: 1.8 \mathrm{~m}\right)$ forms in the study area (Fig. 7) but had the lowest slope $\left(\mathrm{S}_{\text {mean }}: 0.0052\right)$. The evolution of type $A 2$ fluvial levees continued for a long time but was terminated by channel narrowing in the mid-twentieth century; therefore, these levees had narrower $\left(\mathrm{W}_{\text {mean }}: 173 \mathrm{~m}\right)$ and lower $\left(\mathrm{H}_{\text {mean }}: 1.4 \mathrm{~m}\right)$ features than the type A1 levees. The largest number of old fluvial levees belonged to type A3. Their width was similar to those of the $A 2$ levees $\left(\mathrm{W}_{\text {mean }}: 187 \mathrm{~m}\right.$ ), but their average height $\left(\mathrm{H}_{\text {mean }}: 1.1 \mathrm{~m}\right)$ was the lowest of the A types because these levees moved relatively farther from the active channel during the last ca. 150 years as the adjacent meanders were cut off. The spatial distribution of these types was determined by the spatiality of the nineteenth century regulation works (Fig. 8). The type A1 and A2 fluvial levees remained where the meanders of the Maros were not very sharp and thus were not cut off. Such unmanaged units were located in the upstream (units 1-3) and middle sections (units 10-19). The evolution of the type A3 levees was terminated by cutoffs, so these levees were located where the channel was straightened; thus, these levees could be found behind the members of type $B$.

The type B fluvial levees ( $40 \%$ of the identified landforms) developed since the nineteenth century cutoffs and thus formed along the artificial, usually straight or slightly sinuous channel sections (Fig. 8). These levees were almost as wide and as high landforms as the fluvial levee types A2 and A3 (Fig. 7), although they have steeper slopes (by 38\%). The members of the actively developing type B1 were higher and steeper $\left(\mathrm{H}_{\text {mean }}: 1.7 \mathrm{~m}, \mathrm{~S}_{\text {mean }}\right.$ : 0.0159) than the type B2 fluvial levees $\left(\mathrm{H}_{\text {mean }}: 1.5 \mathrm{~m}, \mathrm{~S}_{\text {mean }}\right.$ : 0.0084$)$ because the development of the latter was terminated by channel narrowing. Generally, the type B fluvial levees were higher along the wider channel sections because lateral erosion was more intensive here and the channel material could be deposited along the banks. As the channel of the Maros was straightened in the upper section (units 5-12) and downstream of the no. 20 unit, type B1 and B2 fluvial levees appear along these sections.

Table 1

Ranges of the characteristic morphometric parameters (width, height, and slope) of the fluvial-levee types; $\mathrm{n}$ : size of the sample population.

\begin{tabular}{|c|c|c|c|c|c|c|c|c|c|c|}
\hline \multirow[t]{2}{*}{ Type } & \multirow[t]{2}{*}{$\mathrm{n}$} & \multicolumn{3}{|c|}{ Width (m) } & \multicolumn{3}{|c|}{ Height (m) } & \multicolumn{3}{|l|}{ Slope } \\
\hline & & Min. & Mean & Max. & Min. & Mean & Max. & Min. & Mean & Max. \\
\hline A1 & 6 & 210 & 441 & 1022 & 1.3 & 1.8 & 2.2 & 0.0016 & 0.0052 & 0.0076 \\
\hline A2 & 4 & 78 & 173 & 33 & 0.8 & 1.4 & 1.9 & 0.0056 & 0.0074 & 0.0092 \\
\hline A3 & 9 & 69 & 187 & 329 & 0.3 & 1.1 & 2.9 & 0.0031 & 0.0061 & 0.0165 \\
\hline B1 & 14 & 42 & 182 & 768 & 0.4 & 1.7 & 2.8 & 0.0051 & 0.0159 & 0.0420 \\
\hline B2 & 7 & 63 & 208 & 391 & 1.0 & 1.5 & 2.1 & 0.0043 & 0.0084 & 0.0174 \\
\hline C & 12 & 18 & 46 & 79 & 0.7 & 1.6 & 3.1 & 0.0220 & 0.0428 & 0.0991 \\
\hline
\end{tabular}

The members of type $C$ constituted $12 \%$ of the fluvial levees. These levees were the youngest landforms because they evolved on the new low-lying floodplain surfaces that formed after channel narrowing (Figs. 6 and 8). Although these forms were the narrowest $\left(\mathrm{W}_{\text {mean }}\right.$ : $46 \mathrm{~m})$, they were high $\left(\mathrm{H}_{\text {mean }}: 1.6 \mathrm{~m}\right)$ and thus had the steepest slopes ( $S_{\text {mean }}$ : 0.0428). Type $C$ fluvial levees were almost evenly distributed along the study area, as $75 \%$ of the studied Maros reach was intensively narrowed. Type $C$ levees were missing near the confluence (units 2531 ) because the channel slightly widened at this location.

\subsection{Morphological comparison of the active fluvial levee types}

The studied fluvial levees began to evolve at different dates, and their development ended in different fashions, so only the morphologies of the still active fluvial levees (types A1, B1, and C) were compared in detail.

The oldest (A1) fluvial levees began to develop during preregulation times, so their mean width were ca. four times greater than those (B1) that developed after the river regulations and 18 times wider than the type $C$ features, which began to develop on the low-lying benches after the 1950s (Figs. 7-9). However, their heights were quite similar, although the average values decreased with decreasing age. Thus, the greatest slopes characterised the type $C$ levees, which were eight times steeper than the type A1 levees and more than three times steeper than the type $\mathrm{B} 1$ levees.

Technically, no correlation existed between different parameters of the same type, although the $R^{2}$ values decreased with decreasing age. For example, the $R^{2}$ value between the width and slope of the active fluvial levees was 0.76 for type A1 but only 0.56 for type B1 and only 0.19 for type $C$. The same tendency was also found between the width and height values of the fluvial levees.

\subsection{Fluvial levee development and flood recurrence intervals}

We could calculate the recurrence interval of the floods that overflowed the various levee types and contributed to their vertical aggradation based on the elevation of the highest point of each fluvial levee. The type A1 fluvial levees were covered by at least $490-\mathrm{cm}$-high floods (Fig. 10), which had an 11.9-year recurrence interval. The earlier the development of the type A levees terminated, the lower the flood level that was required for their inundation (A2: 462-cm stage and RI: 8.4 years, A3: $455-\mathrm{cm}$ stage and RI 7.8 years). The type B levees were located along artificially straightened, higher energy sections and had already grown high, so only higher (B1: $550 \mathrm{~cm}, \mathrm{~B} 2: 514 \mathrm{~cm}$ ) floods could cover them with a greater recurrence interval (B1: 38 years, B2: 20.5 years). The type $C$ levees evolved on low-lying floodplain benches, 

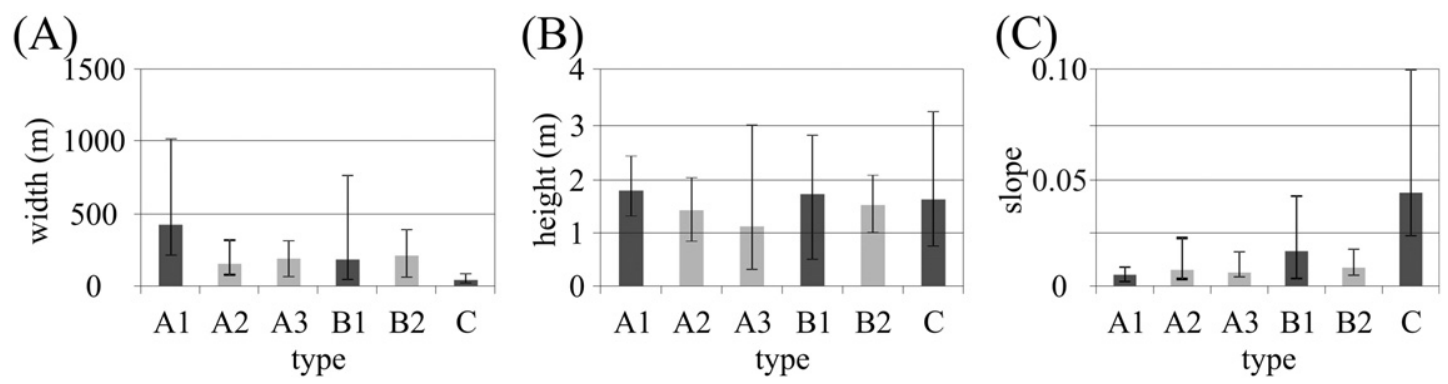

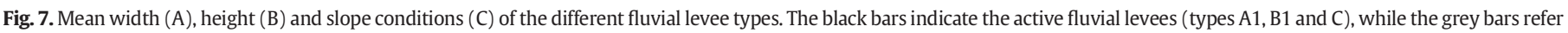
to terminated development (types $\mathrm{A} 2, \mathrm{~A} 3$ and $\mathrm{B} 2$ ).

so one would expect frequent flooding. However, these levees had already grown quite high; so at least 475-cm-high floods were required to cover them and continue their aggradation, but the recurrence interval of these floods was 9.6 years.

\subsection{Grain-size characteristics of the active fluvial levee types}

The grain-size distributions of the active fluvial levees were also evaluated from the perspective of (i) downstream changes and (ii) vertical variations within the same section. The grain size of the type A1 and B1 levees decreased toward the downstream areas (Fig. 11). For example, the material of the type A1 levees is dominantly medium- and fine-grained sand in the upper units, sand and silt occur in almost equal proportions in the middle units, and mostly fine-grained material is present in the lower units. However, downstream grain-size changes were not evident in the type $C$ fluvial levees because their material consisted of a high proportion (71-91\%) of sand. Furthermore, the material of the type $C$ features was always coarser than that of the nearby A1 or B1 fluvial levees.

The vertical grain-size profile of one member of each active fluvial levee type was evaluated in the middle (12-15) units (Fig. 12). These profiles were compared to earlier grain-size and palynological results from the same area (Kiss et al., 2011), enabling us to date the profiles. The sampled type A1 fluvial levee was the highest and thus has the longest profile. The lowermost samples (zone I) were characterised by fine sand and silt and were slightly dark coloured, so these samples probably represent the original surface before the evolution of the fluvial levee. The material in zone I was covered by slightly coarser but predominantly fine sandy deposits (zone II), referring to their proximity to the active channel. Later, even coarser material accumulated at the site (zone III), which was probably deposited when the fluvial levee began to develop at the sampling point. Upward, the material in the type A1 levee became slightly finer (zone IV), referring to a less prominent depositional environment. The material in the type B1 fluvial levee was deposited on this finegrained, silty-sandy material. The type B1 fluvial levees evolved along artificial channel sections, which intensively widened in the nineteenth century (Laczay, 1975); thus, zone V, where the sand fraction is predominant, represents the period of cutoffs when the bedload transport considerably increased. In the A1 and B1 profiles, a fine-grained layer (zone VI) covered the sandy material. The uppermost (VII) zone was built from the coarsest material and consists of coarse- and fine-grained sandy sediments. This zone is represented in each type and thus was probably deposited simultaneously, although this zone became coarser and its depth increased as the fluvial levee became younger $(A 1: 30 \mathrm{~cm}, \mathrm{~B} 1$ : $65 \mathrm{~cm}$, and $\mathrm{C}: 110 \mathrm{~cm}$ ). All the sediments in the type C fluvial levee belonged to this zone, which suggests that the material was deposited after the 1950s. The material in the type $C$ levee was more homogenous than that in the other types because of rapid development from a lower number of floods.

\subsection{Downstream changes and the effect of available space on the morphology of active fluvial levees}

The downstream changes in the parameters of the active fluvial levees were also evaluated (Fig. 13) to reveal whether the morphological properties of the alluvial fan - floodplain complex influenced the evolution of the active fluvial levees. High fluvial levees with considerable width developed on the secondary alluvial fan (units 12-20), where they mostly filled the available embanked floodplain space (up to $81 \%$ ). A gradual drop in fluvial levee height was detected from the beginning of the secondary alluvial fan to the confluence of the Maros and Tisza Rivers, which was probably connected to the drop in channel slope

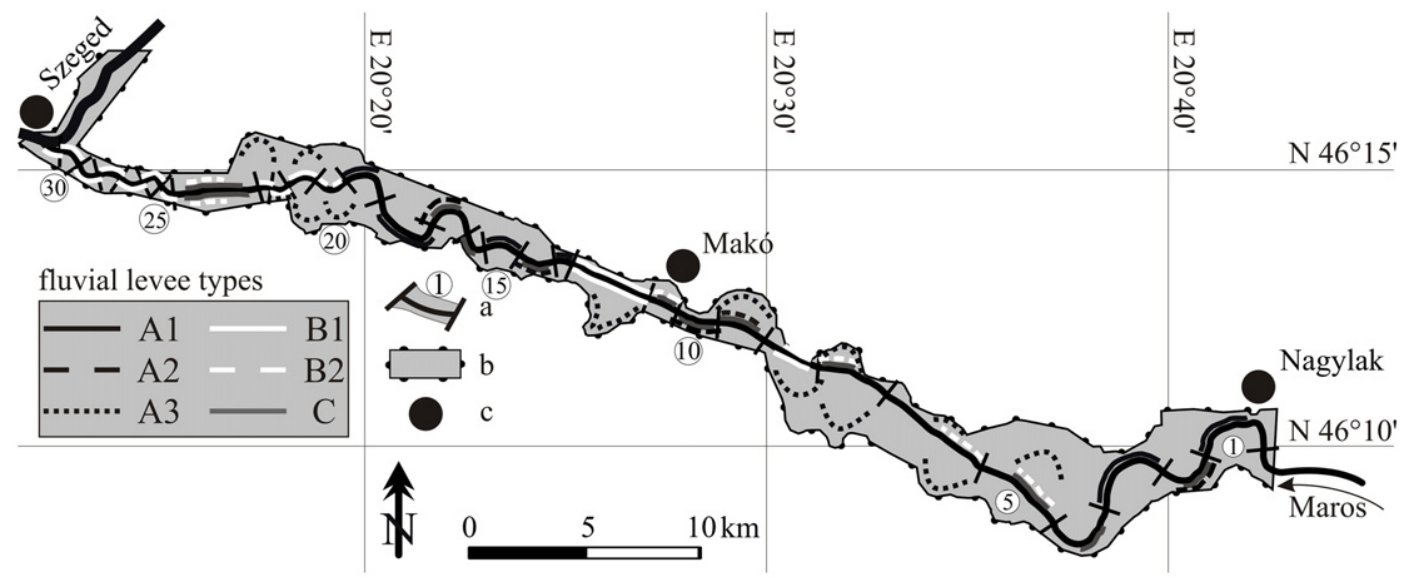

Fig. 8. Spatial distribution of the different fluvial levee types on the studied floodplain of the Maros River. 
(A)

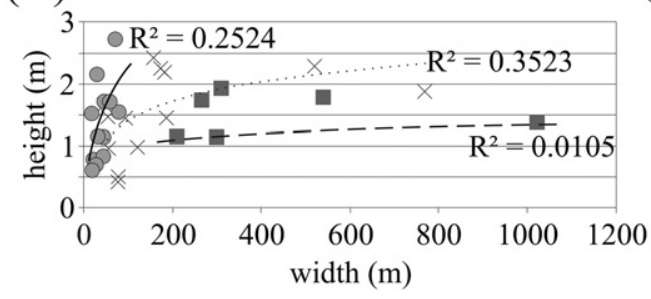

(B)

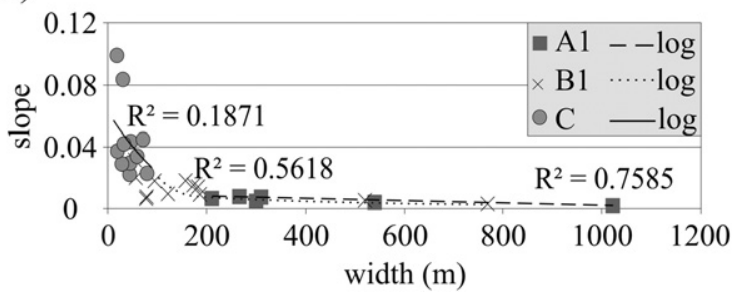

Fig. 9. Correlations between the width, height and slope of the active fluvial levees; log: logarithmic trendline.

from 0.00012 to 0.00002 . The embanked floodplain was relatively wide on the alluvial fan and floodplain units, so the fluvial levees stretched across only a smaller portion (up to 59\%). Some high fluvial levees also developed near the confluence (outlet) because of impounded floods and almost filled the entire narrow embanked floodplain (up to 95\%).

The role of available space on the horizontal development of the active fluvial levee types could also be evaluated. The controlling factor for types A1 and B1 was the width of the embanked floodplain; however for type $C$ it was the width of the new floodplain section (bench). The widest active fluvial levees belonged to type A1, although they filled only $40-80 \%$ (mean: $64 \%$ ) of the embanked floodplain (Fig. 14). This value was more variable (4-100\%) for the younger types B1 and C. While type B1 fluvial levees covered as much as $45 \%$ of the floodplain width on average, type $C$ covered as much as $71 \%$ of the narrow lowlying benches on average.

According to the lateral growth of types A1 and B1 fluvial levees along units 1-20 (which were all situated on the alluvial fan), their horizontal growth was not limited by the width of the embanked floodplain; therefore, the levees became wide and covered $43 \%$ of the width of the floodplain on average (Figs. 13B and 14). In contrast, the evolution of the active fluvial levees in the downstream $(21-31)$ units was impeded by the quite narrow ( $\max : 1.6 \mathrm{~km}$ ) floodplain and the fast lateral migration of the channel $(1.2 \mathrm{~m} / \mathrm{y})$. Here, the bends were very close to the embanked levees; therefore, the lateral expansion of the fluvial levees was restricted, almost filling the entire floodplain (60-100\%). According to the width conditions of fluvial levees from the perspective of available floodplain space, the fluvial levees could have reached the foot of the embanked levees if the floodplain was $<500 \mathrm{~m}$ wide for type A1 and $300 \mathrm{~m}$ for type B1; in each case, the fluvial levees covered at least $50 \%$ of the embanked floodplain. Type $C$ fluvial levees were common along almost the entire studied section of the river (units 2-24), although these features were missing on the widening outlet section. Their development was independent of the width of the embanked floodplain and was instead limited by the width of the low-lying benches. Although the type C fluvial levees were narrow (18-79 m), the floodplain benches were only $20-131 \mathrm{~m}$ wide, so the fluvial levees filled $24-100 \%$ of the available space.

\subsection{Effect of revetments on the morphology of the fluvial levees}

Among the latest engineering works, revetments were built (19461958) to stop the lateral erosion of the channel. Fluvial levees along the fixed banks were 24-36\% higher than those that evolved along freely eroding banks (Fig. 15). However, the width and slope of the affected fluvial levees were not simply connected with the existence of revetments. For example, revetmented type A1 fluvial levees were 50\% narrower $\left(\mathrm{W}_{\text {mean }}: 331 \mathrm{~m}\right)$ and their slope was double $\left(\mathrm{S}_{\text {mean }}: 0.0062\right)$ that of the A1 levees that developed along freely eroding units. In contrast, the B1 and C fluvial levees were two or three times wider along the revetmented units; therefore, their slopes were slightly smaller (by 10-20\%). The A1 fluvial levees responded differently to revetment construction, so their spatial distribution was also analysed. The revetment-free $\mathrm{A} 1$ fluvial levees were located in the uppermost alluvial fan area (units 1-9), while all the revetmented levees were located in the fan-front section (units 12-20), where all the fluvial levees were wider, which explains the difference between their width independently of the existence of revetments.

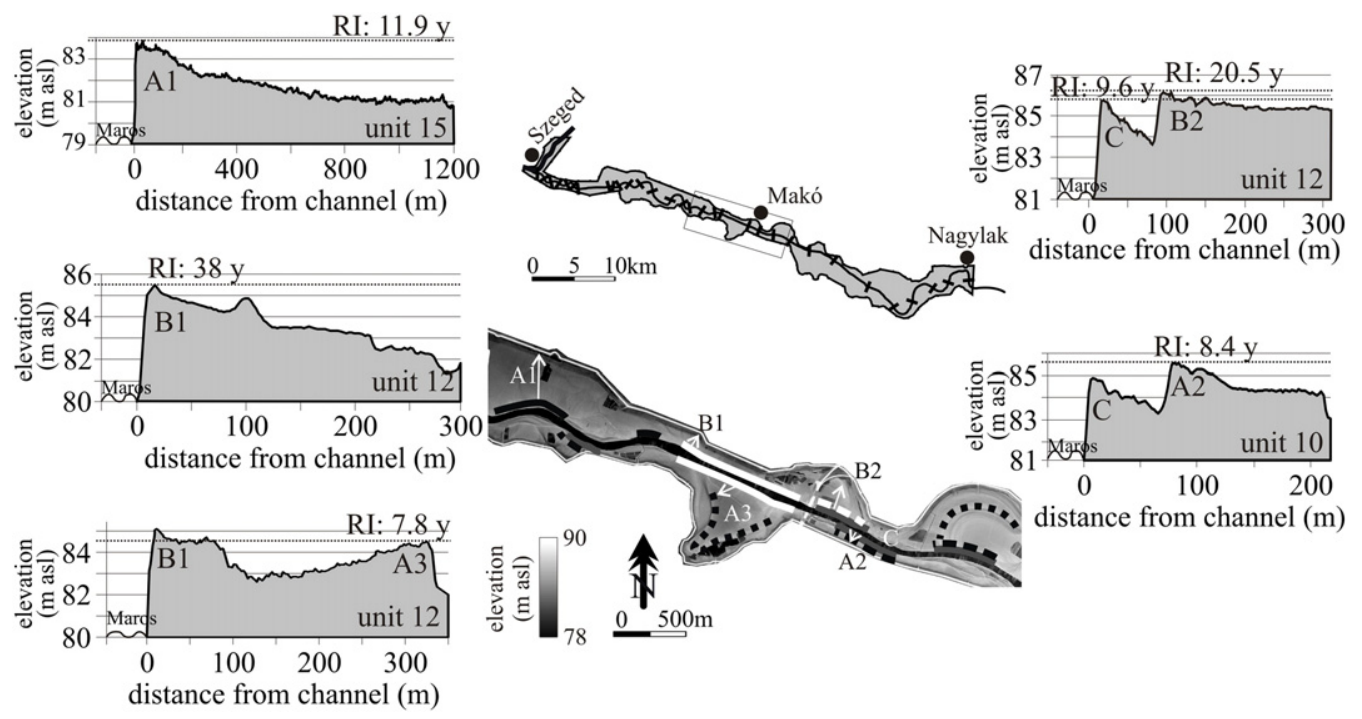

Fig. 10. The recurrence intervals of floods near the Makó gauge station (units 9-15) were calculated, which could overflow the different fluvial levee types. 


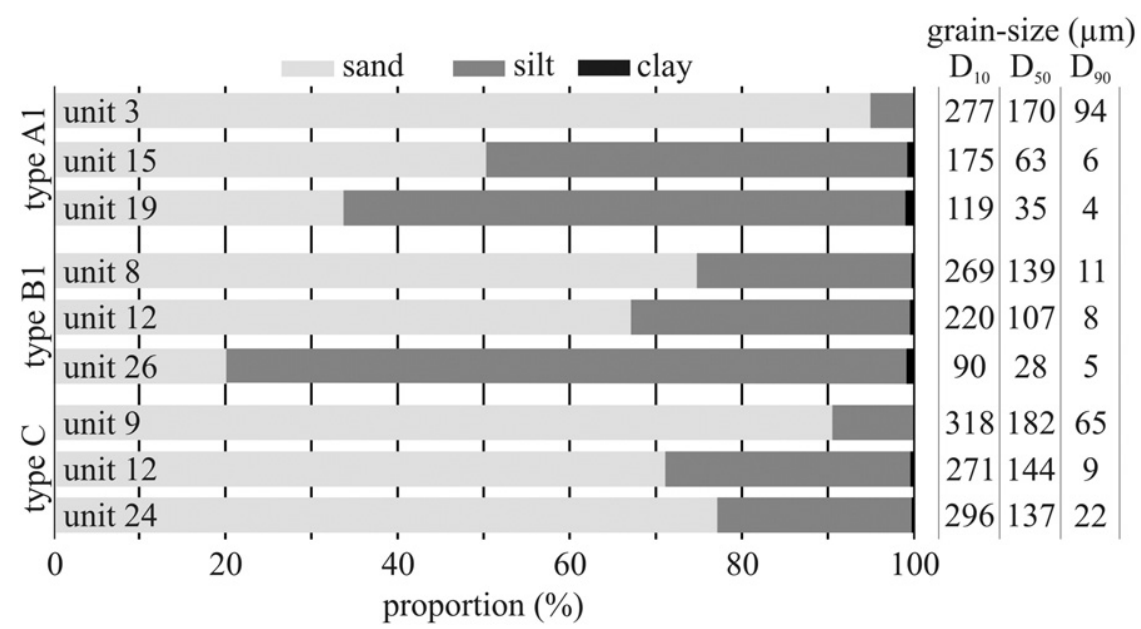

Fig. 11. Downstream grain-size changes in the material of the active fluvial levee types.

\section{Discussion}

\subsection{Human effects on fluvial levee formation}

This study demonstrated that different local human interventions (e.g., cutoffs, revetment, and embanked levee constructions) and channel narrowing that was caused by upstream human activities considerably affected the morphology of fluvial levees (Fig. 16). Similar human-induced morphological changes were described from the highly engineered Rhine and Mississippi rivers (e.g., Hesselink et al., 2003; Hudson et al., 2008; Pierik et al., 2017), Danube River (Klasz et al., 2014), and various Mediterranean rivers (Hooke, 2006).
Along the studied section of the Maros River, 24 meanders were cut off and new straight or slightly sinuous channel sections were created in the mid- and late nineteenth century. Although some pre-regulation fluvial levees (type A1) are still evolving, the development of fluvial levees terminated (type A3) along the cutoff meanders, and new fluvial levees (types B1 and B2) began to grow along the artificial channel sections (Fig. 16). The number of fluvial levees doubled because of these artificial cutoffs. The artificial alteration of these landforms is reflected in how only ca. one-tenth of the fluvial levees (type A1) have continuously developed since preregulation times, and the evolution of most of the forms was influenced by human activities. Similar alteration of floodplain forms was noted by Hesselink et al. (2003)
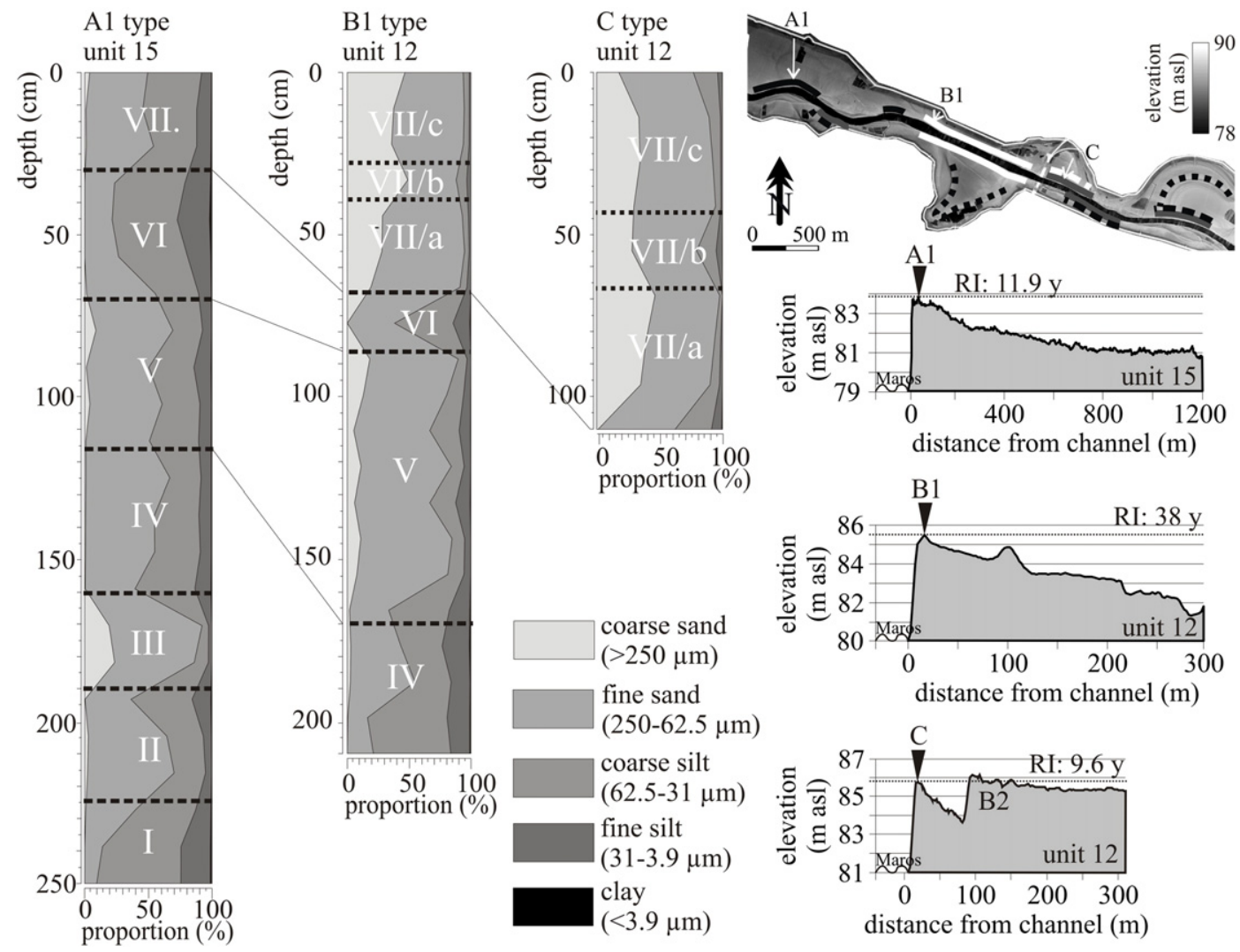

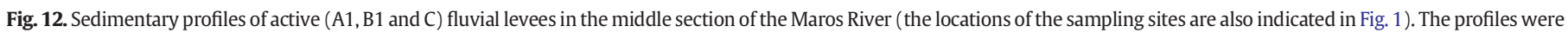
divided into zones $(\mathrm{I}-\mathrm{VII})$ and subzones $(\mathrm{a}-\mathrm{c})$ based on the characteristics of the sediment. 

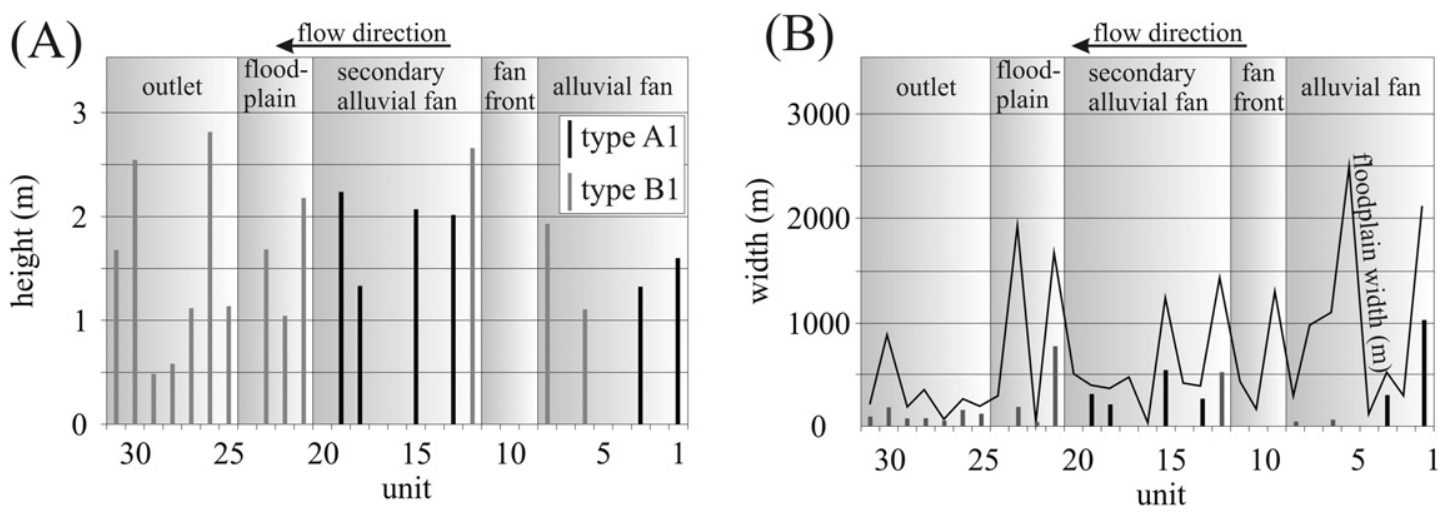

Fig. 13. Downstream changes in the height (A) and width (B) of the type A1 and B1 fluvial levees and the width of the embanked floodplain.

along the embanked Rhine, where the atypical development of bars and secondary channels was revealed.

Embanked levees were constructed simultaneously with channel regulations in the nineteenth century. These artificial levees could spatially limit the horizontal growth of fluvial levees (Klasz et al., 2014) if they were located too close to the channel. The width of the new embanked floodplain of the Maros is quite irregular; therefore, the active fluvial levees occupy the floodplain in various proportions (4-100\%). If the floodplain is $<500 \mathrm{~m}$ wide for the type A1 fluvial levees and $300 \mathrm{~m}$ for type B1, these fluvial levees could reach the foot of the embanked levee (Fig. 16). This threshold value is supported by a sedimentation-pattern measurement after a flood (Oroszi, 2008), as $18 \mathrm{~cm}$ of sandy material was deposited in a ca. 300-m-wide zone along the channel.

The role of revetments was also evaluated for each active fluvial levee type. Under natural conditions, the banks by the fluvial levees were laterally eroded (Schumm, 1969), so accumulation on the fluvial levees was balanced by lateral erosion; additionally, these features could be eroded by sheet/surface wash during extremely high-energy floods (Smith and Pérez-Arlucea, 2008). However, revetments could impede the lateral erosion of the banks and fluvial levees (Fig. 16). Generally, the mean heights of the active fluvial levees were $24-36 \%$ greater than those that developed along freely eroding banks, suggesting a greater aggradation rate or a lack of erosion on the embanked fluvial levees. This observation matches the results of Klasz et al. (2014), who found that revetments increased the aggradation rate of fluvial levees. No clear difference was found between the width and slope of revetmented and freely developing fluvial levees, which suggests that these parameters were influenced by the revetment and by other local factors (e.g., sinuosity of the channel, location of the thalweg).

The effects of late twentieth century water withdrawal, impoundment, and inchannel gravel mining in the upstream Romanian section propagated downstream; thus, the studied lowland section of the

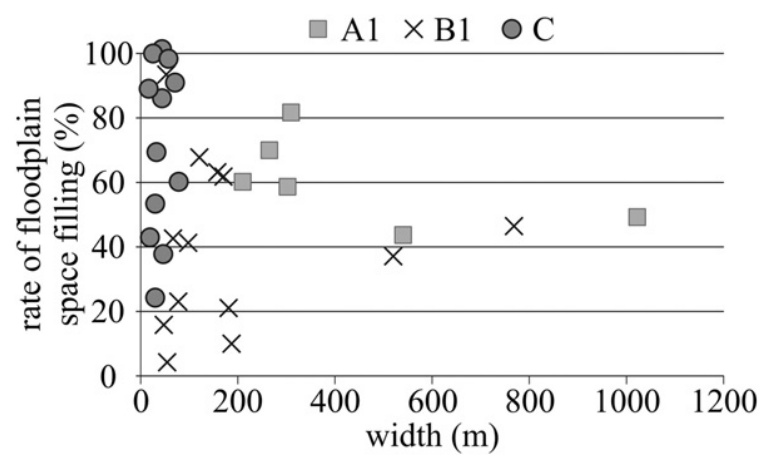

Fig. 14. Correlation between the floodplain space-filling rate and the width of the active fluvial levees.
Maros has become narrower by $24 \%$ since the 1950 s and the channel has been incised by $1.2 \mathrm{~m}$ on average (Kiss et al., 2017) because of declining bedload transport. Low-lying floodplain benches evolved in the narrower and deeper channel (Fig. 16). Such benches were reported in earlier studies (Erskine and Livingstone, 1999; Haney and Davis, 2015); however, the fluvial levees on benches were neglected, although ca. one-fourth of the fluvial levees along the Maros belong to this group. Type $C$ landforms could be considered the third generation of fluvial levees. Narrowing and bench formation were the most intensive in the upper section, so type $\mathrm{C}$ levees appeared only in this location, triggering the inactivity of the older forms. The rapid evolution of type $C$ levees is reflected in their homogenous sedimentary record and by the fact that the level of the bench surfaces was $0.3-1.9 \mathrm{~m}$ below the bankfull stage; thus, the river could transport and deposit a great amount of coarse sediment during smaller near-bankfull floods (Rainato et al., 2017). However, as the fluvial levees on the benches grew higher, only higher floods could cover them; currently, only 9.6-year recurrence-interval floods can deposit material on their surfaces. The importance of the bedload in the development of the type $C$ fluvial levees is reflected in their coarse grain size $\left(D_{90}: 271-318 \mu \mathrm{m}\right)$, which was very similar to the grain size of the bedload (Oroszi and Kiss, 2004), and in their almost uniform particle-size distribution. Similarly, the material in the fluvial levees along the ca. 390-km-long lowland section of the Tisza River did not considerably change (Sándor, 2011), indicating uniform hydromorphological conditions.

In addition to the human-induced local morphological changes, the hydrology of the Maros has been altered by catchment-scale human activities (Kiss, 2014), climate change (Sipos et al., 2014), and land use changes (Oroszi and Kiss, 2006). Water levels have dropped since the 1980s, and all the current fluvial levees can be completely covered by water from 20- to 38-year recurrence-interval floods. Thus, their development can be terminated by river engineering works and limited by disappearing floods. Their formation will probably decline in the future, indicating a loosening connectivity between the channel and the floodplain.

A series of fluvial levees could form from a combined effect of all these direct and indirect human influences, similarly to point bars, where the gradual migration of the channel creates point-bar series (Schumm, 1969). Under natural circumstances, the same lateral channel shift destroys the fluvial levees, so no series of fluvial levees can develop. However, the location of the banklines can be abruptly changed by cutoffs and narrowing or the bankline can become stabilised (by revetments), so the fluvial levees can be disconnected from the channel and new levees can develop, creating fluvial levee series. This process was quite common along the Maros River, where 32 active (still forming) and 21 inactive fluvial levees were identified in the 31 studied units; in 17 units, the number of fluvial levees doubled or tripled. Channel narrowing was more active in the upper portion of the study area (units 1-20), so the type C fluvial levees that developed 
(A)

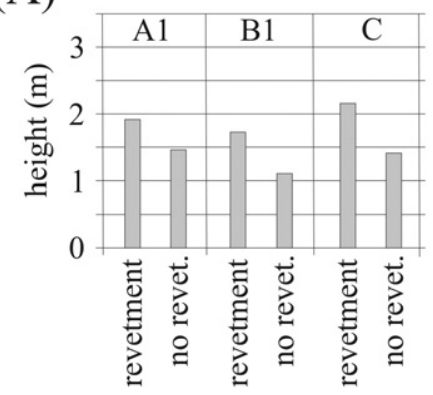

(B)

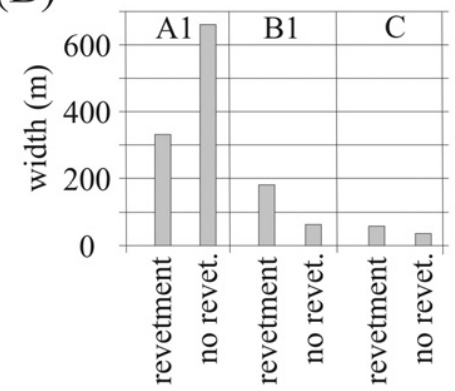

(C)

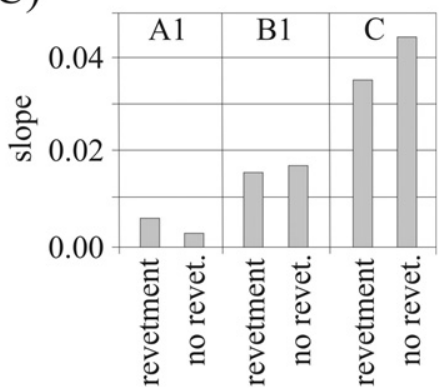

Fig. 15. Comparison of the mean parametric values of the fluvial levees that developed along revetmented banks and freely eroding banks.

here blocked the active development of type A2 and B2 levees. In contrast, cutoffs were more common and channel narrowing was less intensive along the lower section (units 21-31); thus, B1 type fluvial levees are present along the bankline, although type A3 levees exist behind them.

\subsection{Geomorphological characteristics}

The analysis of the morphological parameters revealed that not all the fluvial levees on the floodplain could be analysed as one group. The morphology of the active (types A1, B1, and C) fluvial levees was

\section{(A) Human activities and fluvial levee types}

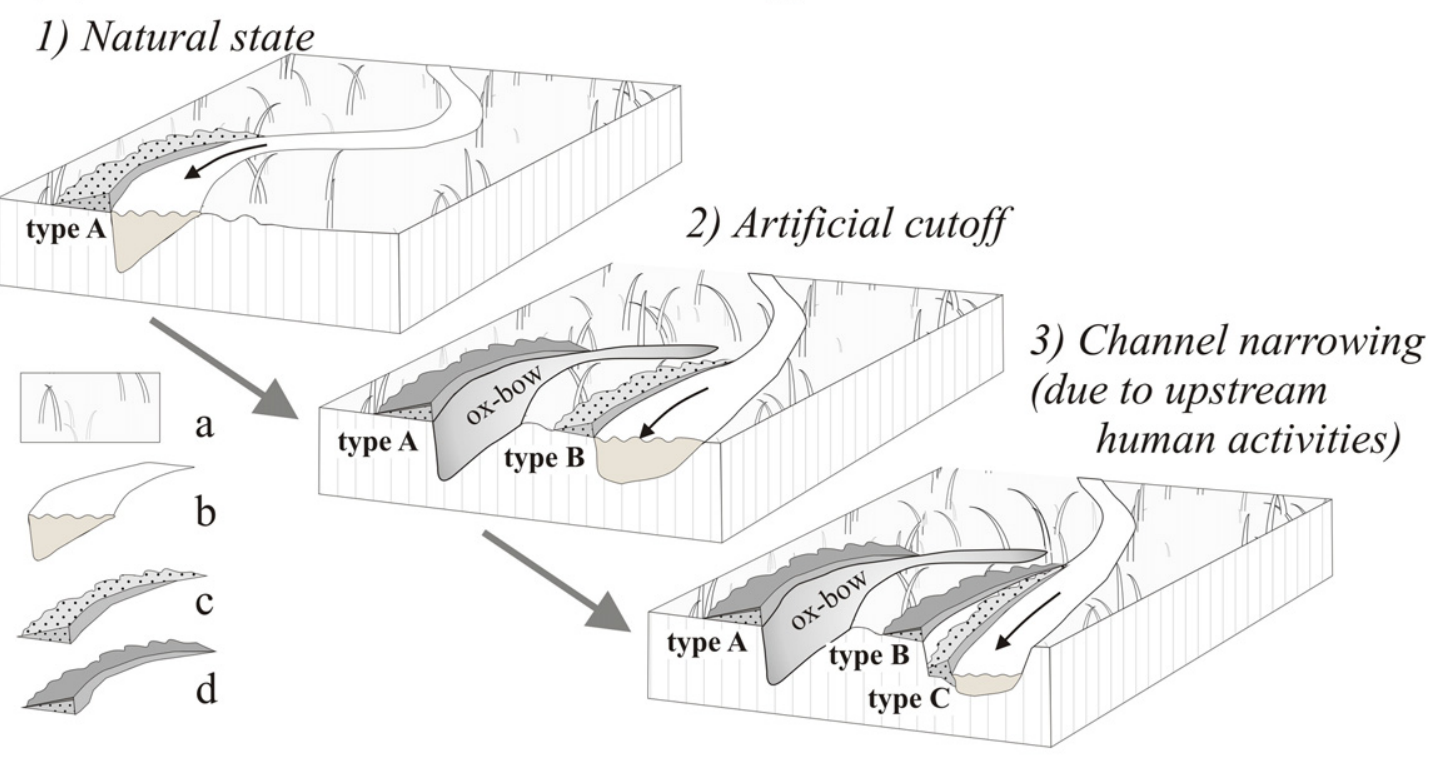

(B) Human activities and fluvial levee size

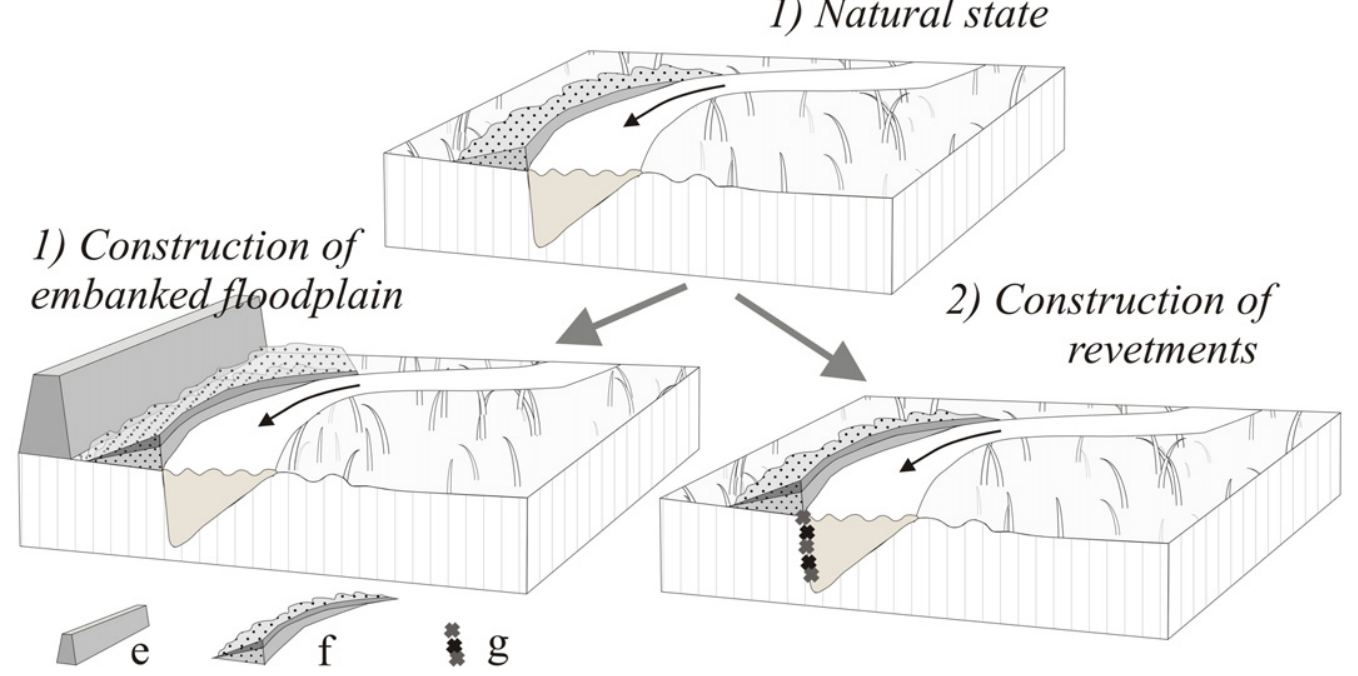

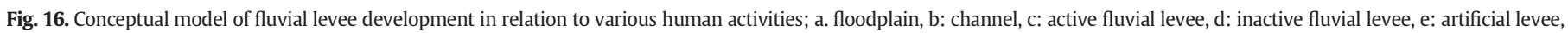
f: accelerated accumulation, g: revetment. 
comparable, and the inactive (types A2-3 and B2) fluvial levees should be handled separately. Generally, older fluvial levees were wider and slightly higher than younger levees; the latter group had greater slopes, corresponding to the data of Cazanacli and Smith (1998). However, the weakening correlation between the parameters with younger ages of the levees suggests that human activities superseded other external factors, as suggested by Lane (1955) and Schumm (1969).

The different fluvial-levee types could be fitted to the model of Adams et al. (2004) based on their development history and slope conditions. Types $\mathrm{C}$ and $\mathrm{B}$ developed in confined floodplain areas: type B fluvial levees began to evolve during the artificial levee constructions on the embanked floodplain, while type $C$ levees developed on the low-lying benches in the narrowing channel. In accordance with the model of Adams et al. (2004), diffusive sediment transport is responsible for the formation of narrow and steep fluvial levees in such a fluvial environment. In the confined area, type $C$ fluvial levees had the greatest slope $\left(S_{\text {mean }}: 0.042\right)$, while type B1 ( $\left.S_{\text {mean }}: 0.0159\right)$ and B2 levees $\left(S_{\text {mean }}: 0.0084\right)$ had more moderate slopes. In contrast, type A levees began to develop on the wide, unconfined natural floodplain and were probably formed by advection, creating broad and gently sloping $\left(S_{\text {mean }}: 0.005-0.007\right)$ fluvial levees. The different energy conditions during the levees' formation were also indicated by their different grain-size distributions.

Type $\mathrm{C}$ levees had the coarsest material and steep slopes, matching the previous results of Cazanacli and Smith (1998). The morphology of type $C$ levees contradicts the findings of Klasz et al. (2014) because these forms were almost as high as the A and B forms, although the available space for their formation was much more limited.

\section{Conclusions}

This study demonstrated that the development and morphology of fluvial levees could be fundamentally influenced by human activities, resulting in (i) the development of fluvial levee series, similarly to point-bar series, and (ii) morphological alterations of the features (height and slope increases) compared to their natural counterparts.

Based on the spatial and temporal characteristics of the fluvial levees, six generation types were distinguished on the Maros River according to the beginning (i.e., pre-nineteenth, nineteenth, and twentieth centuries) and end of their development (i.e., nineteenth and twentieth centuries or still active), which were all connected to various local- and catchment-scale human activities and resulted in channel changes (relocation of the channel and narrowing). Artificial cutoffs and channel narrowing created low-lying floodplain benches (because of upstream water retention and inchannel gravel mining) and were responsible for the development of different fluvial-levee types, while the other local engineering works (e.g., revetment and embanked constructions) influenced their morphology.

The banklines were artificially changed by cutoffs and channel narrowing, so a series of fluvial levees with 2-3 members evolved in succession: as soon as the development of a new fluvial levee began, the evolution of the previous levee terminated. The disconnected features moved relatively farther from the active channel, so (i) no coarse material was deposited on their surfaces, (ii) the lateral channel migration did not affect the levees, and (iii) only suspended sediment could accumulate on their surfaces during large floods. The Maros River has high sediment load, so new fluvial levees developed quite rapidly along the new banklines, and their heights became almost identical to those of their older counterparts.

Additionally, the hydrology of the Maros River changed (i.e., drop in stages, declining floods), so even the active fluvial levees could be flooded by $12-35$-year recurrence-interval floods, which suggests that their formation also became very limited. Even the development of newly formed active (B and C) fluvial levees could cease in the future if channel narrowing continues and floods disappear.
As far as fluvial levees can be considered indicators of connectivity between a channel and floodplain (Fryirs and Brierley, 2012), this study proved that the development of fluvial-levee series in connection with human activity is an indicator of decoupling. This decoupling was also supported by the high recurrence intervals of floods, which could overflow the fluvial levees and contribute to their vertical aggradation.

The application of a LiDAR-based DTM facilitated a detailed morphological analysis of a long and densely vegetated section of the river, so a relatively large number of fluvial levees could be compared. Unfortunately, the disadvantage of this method originates from its great accuracy: the locations of the measurements must be very carefully chosen because the measured data are very sensitive even to the smallest elevation differences. However, the spatial analysis of other floodplain forms (i.e., crevasses, point bars, islands) should become possible in the future by applying a LiDAR-based DTM, and the slope conditions of the banks should provide insight into channel processes.

\section{Acknowledgements}

This research was supported by the Hungarian Scientific Research Fund (OTKA 119 193) and the National Excellence Program of Hungary (NTP-NFTÖ-17-B-0332). We are very grateful to four anonymous reviewers and Dr. Richard Martson for their constructive suggestions that helped to improve our manuscript.

\section{References}

Abate, M., Nyssen, J., Steenhuis, T.S., Moges, M.M., Tilahun, S.A., Enku, T., Adgo, E., 2015 Morphological changes of Gumara River channel over 50 years, upper Blue Nile basin, Ethiopia. J. Hydrol. 525, 152-164.

Adams, P.N., Slingerland, R.L., Smith, N.D., 2004. Variations in natural levee morphology in anastomosed channel flood plain complexes. Geomorphology 61, 127-142.

Allen, J.R.L., 1965. A review of the origin and characteristics of recent alluvial sediments. Sedimentology 5, 89-191.

Blanka, V., Kiss, T., 2006. Case study on meander development of the downstream section of River Maros. Hidrológiai Közlöny 86 (4), 19-22 (in Hungarian).

Blanka, V., Sipos, Gy, Kiss, T., 2006. Spatial and Temporal Changes of Meander Formation on the Hungarian Section of the River Maros. In: Dövényi, Z., Kocsis, K. (Eds.), Kertész. Á. III. Magyar Földrajzi Konferencia, MTA-FKI, Budapest, pp. 1-10 (in Hungarian).

Bogárdi, J., 1971. Sediment Transport of Rivers. Akadémiai Kiadó, Budapest, Hungary 837 pp. (In Hungarian).

Brierley, G.J., Ferguson, R.J., Woolfe, K.J., 1997. What is a fluvial levee? Sediment. Geol. 114, $1-9$.

Brown, A.G., 1983. An analysis of overbank deposits of a flood at Blandford-forum, Dorset England revue. Geomorphologie Dynamique 32, 95-99.

Cazanacli, D., Smith, N.D., 1998. A study of morphology and texture of natural levees, Cumberland Marshes, Saskatchewan, Canada. Geomorphology 25, 43-55.

Chalov, R.S., 2004. Morphological expressions of river sediment transport and their role in channel processes. IAHS Publ. 288, 205-211.

Dufour, S., Piégay, H., 2005. Restoring Floodplain Forests. In: Mansourian, S., Vallauri, D. Dudley, N. (Eds.), Forest Restoration in Landscapes: Beyond Planting Trees. Springer, New York, pp. 306-312.

Erskine, W.D., Livingstone, E.A., 1999. In-Channel Benches: The Role of Floods in their Formation and Destruction on Bedrock-Confined Rivers. In: Miler, A., Gupta, A. (Eds.), Varieties of Fluvial Form. John Wiley and Sons, Chichester, UK, pp. 445-475.

Fisk, H.N., 1947. Fine-Grained Alluvial Deposits and their Effects on Mississippi River Activity. Mississippi River Commission. Vicksburg, p. 82.

Fryirs, K.A., Brierley, G.J., 2012. Geomorphic Analysis of River Systems: An Approach to Reading the Landscape. Wiley-Blackwell, Chichester, p. 360.

Haney, N.R., Davis, L., 2015. Potential controls of alluvial bench deposition and erosion in southern piedmont streams, Alabama (USA). Geomorphology 241, 292-303.

Hesselink, A.W., Weerts, H.J.T., Berendsen, H.J.A., 2003. Alluvial architecture of the human-influenced river Rhine, The Netherlands. Sediment. Geol. 161, 229-248.

Hooke, J.M., 2006. Human impacts on fluvial systems in the Mediterranean region. Geomorphology 79, 311-335

Hudson, P.F., Heitmuller, F.T., 2003. Local and watershed-scale controls on the spatial variability of natural levee deposits in a large fine-grained floodplain: lower Pánuco Basin, Mexico. Geomorphology 56, 255-269.

Hudson, P.F., Middelkoop, H., Stouthamer, E., 2008. Flood management along the Lower Mississippi and Rhine rivers (The Netherlands) and the continuum of geomorphic adjustment. Geomorphology 101, 209-236.

Hughes, F.M.R., 1997. Floodplain biogeomorphology. Prog. Phys. Geogr. 21, 501-529.

Ihrig, D., 1973. History of the River Regulations in Hungary. VízDOK, Budapest. pp. 356-361 (in Hungarian).

James, L.A., Hodgson, M.E., Ghoshal, S., Latiolais, M.M., 2012. Geomorphic change detection using historic maps and DEM differencing: the temporal dimension of geospatial analysis. Geomorphology 137, 181-198. 
Keen-Zebert, A., Tooth, S., Rodnight, H., Duller, G.A.T., Roberts, H.M., Grenfell, M., 2013. Late Quaternary floodplain reworking and the preservation of alluvial sedimentary archives in unconfined and confined valleys in the eastern interior of South Africa. Geomorphology 185, 54-66.

Kiss, T., 2014. Altered Fluvial Processes Due to Human Impacts: Evaluating Equilibrium and Sensitivity of Fluvial Systems. D.Sc, Dissertation, Hungarian Academy of Sciences, Hungary (in Hungarian).

Kiss, T., Sándor, A., Gresó, Zs., 2004. Investigations on the rate of floodplain sediment accumulation in the Mártély embayment of the Lower Tisza. Acta Universitatis Szegediensis. Acta Geographica 38, 15-26.

Kiss, T., Oroszi, V.Gy., Sipos, Gy, Fiala, K., Benyhe, B., 2011. Accelerated overbank accumulation after nineteenth century river regulation works: a case study on the Maros River, Hungary. Geomorphology 135, 191-202.

Kiss, T., Sümeghy, B., Sipos, Gy, 2014. Late Quaternary paleodrainage reconstruction of the Maros River alluvial fan. Geomorphology 204, 49-60.

Kiss, T., Nagy, Z., Balogh, M., 2017. Floodplain level development induced by human activity - case study in the Lower Maros/Mures River, Romania and Hungary. Carpathian J. of Earth and Envi. Sciences 12 (1), 83-93.

Klasz, G., Reckendorfer, W., Gabriel, H., Baumgartner, C., Schmalfuss, R., Gutknecht, D., 2014. Natural levee formation along a large and regulated river: the Danube in the National Park Donau-Auen, Austria. Geomorphology 215, 20-33.

Laczay, I., 1975. River system and catchment of the Maros River. Vízrajzi Atlasz 19, VITUKI Budapest, Hungary, pp. 4-23 (in Hungarian).

Laczay, I., 1982. Morphological foundations of river engineering. Vízügyi Közlemények. 64 (2), 235-254 (in Hungarian).

Lane, E.W., 1955. The importance of fluvial geomorphology in hydraulic engineering. Proc. Am. Soc. Civ. Eng. 81, 1-17.

Makaske, B., Smith, D.G., Berendsen, H.J.A., de Boer, A.G., van Nielen-Kiezebrink, M.F. Locking, T., 2009. Hydraulic and sedimentary processes causing anastomosing morphology of the upper Columbia River, British Columbia, Canada. Geomorphology $111,194-205$.

Middelkoop, H., Asselmann, N.E.M., 1998. Spatial variability of floodplain sedimentation at the event scale in the Rhine-Meuse delta, The Netherlands. Earth Surf. Process. Landf. 23 (6), 561-573.

Nanson, G.C., Croke, J.C., 1992. A genetic classification of floodplains. Geomorphology 4 459-486.

Notebaert, B., Verstraeten, G., Govers, G., Poesen, J., 2009. Qualitative and quantitative applications of LiDAR imagery in fluvial geomorphology. Earth Surf. Process. Landf. $34,217-231$.

Oroszi, V.Gy., 2008. Overbank accumulation caused by the 2006 spring flood on the Maros. In: Kiss, T., Mezősi, G. (Eds.), Recens geomorfológiai folyamatok sebessége Magyarországon. SZTE-TFGT, Szeged, pp. 73-83 (in Hungarian).

Oroszi, V.Gy., Kiss, T., 2004. The analysis of sediment accumulation and silting-up of cut-off channel on River Maros near the city of Makó. Acta Universitatis Szegediensis Acta Geographica 38, 27-38.

Oroszi, V.Gy., Kiss, T., 2006. Landuse change in on the river Maros since the 19th century Tájökológiai Lapok 4 (2), 309-316.

Oroszi, V.Gy., Kiss, T., Sipos, Gy, 2005. Alluviation of active floodplain accelerated by river channelization along the Hungarian Maros river. In: Barton, G., Dormány, G. (Eds.), A Magyar Földrajz Kurrens Eredményei. Szeged, Hungary, pp. 1-20 (in Hungarian).

Palaseanu-Lovejoy, M., Thatcher, C.A., Barras, J.A., 2014. Levee crest elevation profiles derived from airborne LiDAR-based high resolution digital elevation models in south Louisiana. Journal of Photogrammetry and Remote Sensing 91, 114-126.

Piégay, H., Arnaud, D., Souchon, Y., 2003. Effects of riparian vegetation on river channel geometry: case studies from the Massif Central (France). Géomorphologie 9 (2) $111-128$
Pierik, H.J., Stouthamer, E., Cohen, K.M., 2017. Natural levee evolution in the Rhine-Meuse delta, the Netherlands, during the first millennium CE. Geomorphology 295, 215-234.

Rainato, R., Mao, L., Picco, L., 2017. Near-bankfull floods in an alpine stream: effects on the sediment mobility and bedload magnitude. Int. J. of Sediment Research (in press) (https://doi.org/10.1016/j.ijsrc.2017.03.006).

Sándor, A., 2011. Floodplain aggradation along the middle- and lowland section of river Tisza. Ph.D. Dissertation, Univ. Szeged, Hungary (in Hungarian).

Schumm, S.A., 1969. River metamorphosis. J. Hydraul. Div., ASCE 95(HY1), pp. 255-273.

Searcy, J.K., 1959. Flow-duration curves. USGS Water Suppl. Pap. 1542-A, 33.

Sipos, Gy, 2006. Channel dynamics on the Hungarian section of river Maros. Ph.D. Dissertation, Univ. Szeged, Hungary (in Hungarian).

Sipos, Gy, Kiss, T., Fiala, K., 2007. Morphological alterations due to channelization along the lower Tisza and Maros rivers (Hungary). Geogr. Fis. Din. Quart. 30, 239-247.

Sipos, Gy, Blanka, V., Mezősi, G., Kiss, T., van Leeuwen, B., 2014. Effect of climate change on the hydrological character of river Maros, Hungary-Romania. Journal of Environmental Geography 7 (1-2), 49-56.

Smith, L.M., 1996. Fluvial geomorphic features of the lower Mississippi alluvial valley. Eng. Geol. 45, 139-165.

Smith, N.D., Pérez-Arlucea, M., 2008. Natural levee deposition during the 2005 flood of the Saskatchewan River. Geomorphology 101, 583-594.

Sorrells, R.M., 2012. Hydrogeomorphology of Alluvial Benches in an Anabranching Reach of the Upper Yadkin River. North Carolina. PhD dissertation, UNC, Greensboro, NC.

Steiger, J., Tabacchi, E., Dufour, S., Corenblit, D., Peiry, J.L., 2005. Hydrogeomorphic processes affecting riparian habitat within alluvial channel-floodplain river systems: a review for the temperate zone. River Res. Appl. 21, 719-737.

Stevaux, J.C., Souza, I.A., 2004. Floodplain construction in an anastomosed river. Quat. Int. $114,55-65$

Sümeghy, B., 2014. The evolution history of the Maros river alluvial fan. Ph.D. Dissertation, Univ. Szeged, Hungary (in Hungarian).

Szlávik, L., 2000. Risk of floods on the Hungarian Great Plain. In: Pálfai, I. (Ed.), Importance of Rivers on the Hungarian Great Plain. A Nagyalföld Alapítvány Kötetei 6, pp. 64-84 (in Hungarian).

Taylor, C., 2002. Recognising channel and floodplain forms. Water and rivers Commission, Report No. RR17., Perth, Australia, pp. 1-22.

Trimble, S.W., 2009. Fluvial processes, morphology and sediment budgets in the Coon Creek Basin, WI, USA, 1975-1993. Geomorphology 108, 8-23.

Urdea, P., Sipos, Gy., Kiss, T., Onaca, A., 2012. The Maros/Mureş. In: Sipos, Gy (Ed.), Past, Present, Future of the Maros/Mures River. SZTE-TFGT, Szeged, Hungary, pp. 9-32.

Wierzbicki, G., Ostrowski, P., Mazgajski, M., Bujakowsk, F., 2013. Using VHR multispectral remote sensing and LIDAR data to determine the geomorphological effects of overbank flow on a floodplain (the Vistula River, Poland). Geomorphology 183, 73-81.

Wolfert, H.P., Hommel, P.W.F.M., Prins, A.H., Stam, M.H., 2002. The formation of natural levees as a disturbance process significant to the conservation of riverine pastures. Landsc. Ecol. 17 (1), 47-57.

Wolman, M.G., Leopold, L.B., 1957. River floodplains: some observations on their formation. USGS Professional Papers. 282C, pp. 87-107.

$\mathrm{Xu}, \mathrm{J}$. , 2002. River sedimentation and channel adjustment of the lower Yellow River as influenced by low discharges and seasonal channel dry-ups. Geomorphology 43, 151-164.

Zwolinski, Z., 1992. Sedimentology and geomorphology of overbank flows of meandering river floodplains. Geomorphology 4, 367-379. 